\title{
Civilisations
}

Revue internationale d'anthropologie et de sciences

humaines

$67 \mid 2018$

À l'écoute des transnationalisations religieuses

\section{Transnational affects, transnational worldings: Sikhs sounding sacred songs, making multiple worlds}

Affects transnationaux, mondes transnationaux : chants sacrés sikhs, création de mondes multiples

Inderjit N. Kaur

\section{(2) OpenEdition}

\section{Journals}

Electronic version

URL: https://journals.openedition.org/civilisations/4772

DOI: $10.4000 /$ civilisations. 4772

ISSN: 2032-0442

\section{Publisher}

Institut de sociologie de l'Université Libre de Bruxelles

\section{Printed version}

Date of publication: 12 August 2018

Number of pages: $23-40$

ISBN: 978-2-9602017-2-7

ISSN: 0009-8140

\section{Electronic reference}

Inderjit N. Kaur, "Transnational affects, transnational worldings: Sikhs sounding sacred songs, making multiple worlds", Civilisations [Online], 67 | 2018, Online since 01 January 2022, connection on 08 January 2022. URL: http://journals.openedition.org/civilisations/4772 ; DOI: https://doi.org/10.4000/ civilisations. 4772 


\title{
Tra nsna tio nal a ffe $\mathrm{c}$ ts, tra nsna tio nal wo rld ing s: Sikhs so und ing sa c red so ng s, making multip le wo rlds
}

\author{
Inderjit N. KAUR
}

\begin{abstract}
In this paper, I expand on the concepts of "worlding" and "transnational affect" to analyse how the sounding of sacred song in transnational spaces animates "affective alliances" that enable the building of local and global religious communities, but at the same time engender multiple forms of belonging and complex identities. I focus on a minority religious tradition from India, Sikhism. Over the last century or so, Sikhs have migrated to many countries across all continents, taking their sacred songs with them. They have attempted to integrate into their new locations while also building strong affective connections with a transnational Sikh imaginary shaped by shared aesthetics and ethics. In this paper, drawing on stories of Sikhs from Kenya and the USA, I explore the transnational role of sacred songs that circulate via musicians, amateur and professional, as well as media and broadcasts, to propose that the transnational sounding of sacred songs is a significant invigorator of the everyday affective processes that shape life-worlds and subjectivities with respect to social differences such as caste, race, and gender. Further, and importantly, I argue that the accruals of affect, and the resulting individual subjectivities and lifeworlds are diverse and fluid.
\end{abstract}

Keywords: Transnational worldings, transnational affects, identity, subjectivity, sacred song, Sikhism.

Résumé : Dans cet article, je développe les concepts de "worldings" et d'affect transnational afin d'analyser comment le son du chant sacré, dans les espaces transnationaux, anime des "alliances affectives" qui permettent de créer des communautés religieuses locales et mondiales, mais qui, en même temps, engendrent des formes multiples d'appartenance et d'identités complexes. Je concentre mon étude sur une tradition religieuse minoritaire de l'Inde, le sikhisme. Au cours du siècle dernier, les Sikhs ont migré vers de nombreux pays sur tous les continents, emportant avec eux leurs chants sacrés. Ils ont tenté de s'intégrer dans leurs nouveaux milieux tout en établissant des liens affectifs solides avec un imaginaire sikh transnational façonné par une esthétique et une éthique communes. Dans cet article, je m'inspire de récits de Sikhs du Kenya et des Etats-Unis pour explorer le rôle transnational des chants sacrés qui circulent par l'intermédiaire des musiciens amateurs et professionnels, des médias écrits et oraux, pour suggérer que le son transnational des chants sacrés est un facteur important de stimulation des processus affectifs quotidiens qui influencent les mondes et subjectivités de vie tout en respectant les différences sociales, telles que les castes, les races et les genres. Autre point important, je soutiens que les accumulations d'affects d'une part, et les subjectivités individuelles et les sphères de vie qui en résultent d'autre part, sont diverses et aléatoires.

Mots-clés : mondes transnationaux, affects transnationaux, identité, subjectivité, chants sacrés, sikhisme. 


\section{Introduction}

Founded as recently as the turn of the $16^{\text {th }}$ century in the Punjab region of South Asia, Sikhism is now recognised as the fifth major world religion with followers settled in numerous countries across the globe. The widespread migration of Sikhs has been a result of both pull factors such as economic opportunities, and push factors such as the 1984 anti-Sikh Indian-state-sponsored pogroms in which thousands of ordinary male citizens were tortured and killed within four days, women raped, and property destroyed on a large scale. Wherever Sikhs have migrated and settled, the dominant means of worship and sociality has been congregating around sacred song and accompanying practices. Sacred sound has been an important artery linking Sikhs to each other locally and globally.

In this paper, I analyse the role of sacred songs that circulate via musicians, amateur and professional, as well as media and broadcasts, in the transnational transmission of affect; in particular, how these circulating sacred songs play a crucial role in fostering affective sensibilities and subjectivities among globally distributed Sikhs. I use the term affect here for an intensity that is produced in the interaction between bodies, human and non-human; a potential that lurks in connections between people and things; a mutual force relation between them. The force may be strong or barely perceptible, well below the conscious realm. The force can attract or repel, bind or separate. ${ }^{1}$

My aim is to provide an individualised view of the affective formations of transnational identities and lifeworlds in a religious community. In doing so I supplement the hitherto largely collective-level approach of scholarship that has focused on aspects of religious transnationalism generalisable at the community level, and categorisation of processes such as the transfer of socio-cultural and economic practices from home cultures, and integration of migrants into host cultures (e.g. in the Sikh context, Jacobsen \& Myrvold 2012). ${ }^{2}$ My focus is on the particularities and affective registers of individual experiences to draw attention to the diversity in the complexities and multiple layers that accumulate as transnational lives unfold.

To bring out the singularities of my interlocutors' lifeworlds, I draw on the analytics of "worldings" (Stewart 2011, 2014 \{based on Heidegger 1962\}). The notion of worldings addresses the processes of an individual's world making and thereby foregrounds

1 For discussions of affect, see Massumi (2002), Ahmed (2004), Brennan (2004), Stewart (2007), and Greig \& Seigworth (2010).

2 This is not to say that the existing studies on diaspora and transnationalism in general have not recognised the complexities and affective dimensions of transnational identities. Scholars such as Hall (1990) and Gilroy (1993) have underscored the importance of dynamic formations of diasporic identities. The importance of emotions, in these processes, has been analysed in particular by Ahmad (2004). Ethnomusicological literature on diasporic identities is vast, with a survey on diaspora by Slobin (2011). While research on music and religious transnationalism has not been as abundant, in particular relation to this paper, Ferran (2015) has highlighted ambivalent religious identity within a congregation, and Salzbrunn (2016) has shown the heterogeneity and plurality of political affiliations within a religious community. 
the dynamics at play. In this paper, I propose "transnational worldings" as a concept that attends to the role of the transnational in the everyday. I focus in particular on processes of affective attunements - alignments of sentiments and feelings, to those in sacred song-texts and associated practices and places.

I also offer an expanded notion of "transnational affects" from that proposed by Velayutham and Wise (2005), one that shifts from their focus on the translocal transposition of pre-existing affects and duplication of moral economies, to an attention also to accruals of affects emerging from the interactives between old and new localities - materialities as well as imaginaries. These modified analytics, of worldings and transnational affects, acknowledge and incorporate processes of individual agency and change along with those of accumulation and stickiness (Ahmed 2004), and thus can foreground new, diverse, and overlapping fields of distributions - of affects, subjectivities, belongings and identities.

Additionally, I use non-representational methodologies (Vannini 2015) of storytelling and re-presenting the voice of the interlocutor more directly rather than representing the interlocutor. I base my arguments on fieldwork undertaken during the last decade in different parts of India and the USA, including concentrated fieldwork at the greater San Francisco Bay Area in California over the last two years. My ethnographic method consists of a mix of participant observation, semi-structured interviews with Sikhs living in the USA, Kenya, and England, and study of internet resources such as blogs, forums, YouTube postings, and other websites. To anonymise I use pseudonyms for my interlocutors.

\section{Sikh Sabad Kīrtan (Sacred Song)}

Sikh sonic worship, and it can be said Sikhism itself, started with the sabad (sacred songs) of Guru Nanak (1469-1539) in the western part of Punjab, then India, and since 1947, Pakistan. Guru Nanak travelled widely with his Muslim companion and rabāb (lute) accompanist, Mardana (1459-1534), singing his songs of piety, ethics and social justice (Figure 1). Followed by nine successors (1504-1708), the ten Sikh Gurus (spiritual preceptors who held the status of prophets for their followers, Sikhs \{lit. students\}) shaped Sikh philosophy, practice, and music.

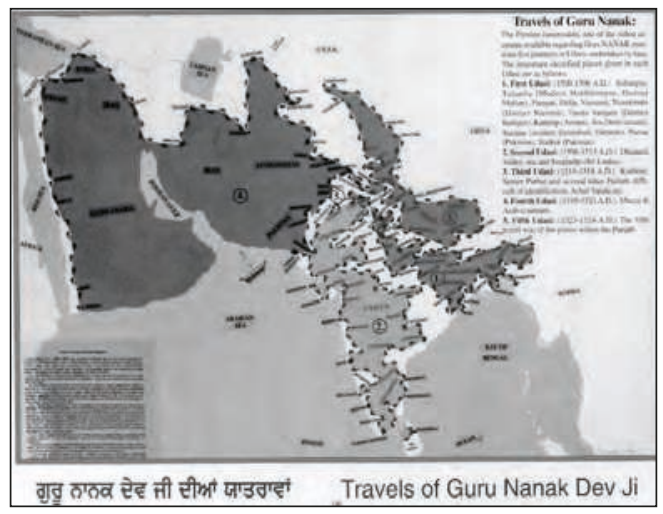

Figure 1. Guru Nanak's major journeys (udasi)

Map of his travels over 24 years (1500-1524), eastward to Assam, southward until Sri Lanka, northward up to Tashkent, and westward to the Arabian Peninsula (C) 〈http://sikhiwiki.org/images/> 
The Sikh Gurus had over 5,000 of their sabad scribed into the Sikh primary scripture, the Guru Granth Sahib (lit. respected spiritual-authority book; Figure 2), and instituted it as the eternal Guru of the Sikhs after the passing of the tenth human Guru. They also included in the scripture a few hundred song-texts from poet-saints from the Hindu and Muslim faith traditions. They sang in diverse musical genres and styles, accompanied on stringed instruments and drums. They institutionalised sabad kirtan (singing of sacred song) as congregational worship, employing professional rabābiss (Muslim hereditary musicians who sang with self-accompaniment on the rabāb) and $r \bar{a} g \bar{\imath} s$ (Sikh musicians, lit. those who sing \{in\} rāg), and instituted the singing of vārs (heroic songs) by $d h \bar{a} \underline{d} \bar{l} s$ (singers who sing with self-accompaniment on the hourglass-shaped handheld drum, dhad.). While a variety of musical genres and ever changing-styles continue to be used for sabad kirtan in India and worldwide (Kaur 2011, 2016a, 2016b; Purewal \& Lallie 2013), only the canonised text in the Sikh scriptures is considered appropriate to use. Sikhs hold a deeply affective relation to Guru Granth Sahib. It is honoured as the embodiment of the wisdom of their revered and beloved Gurus.

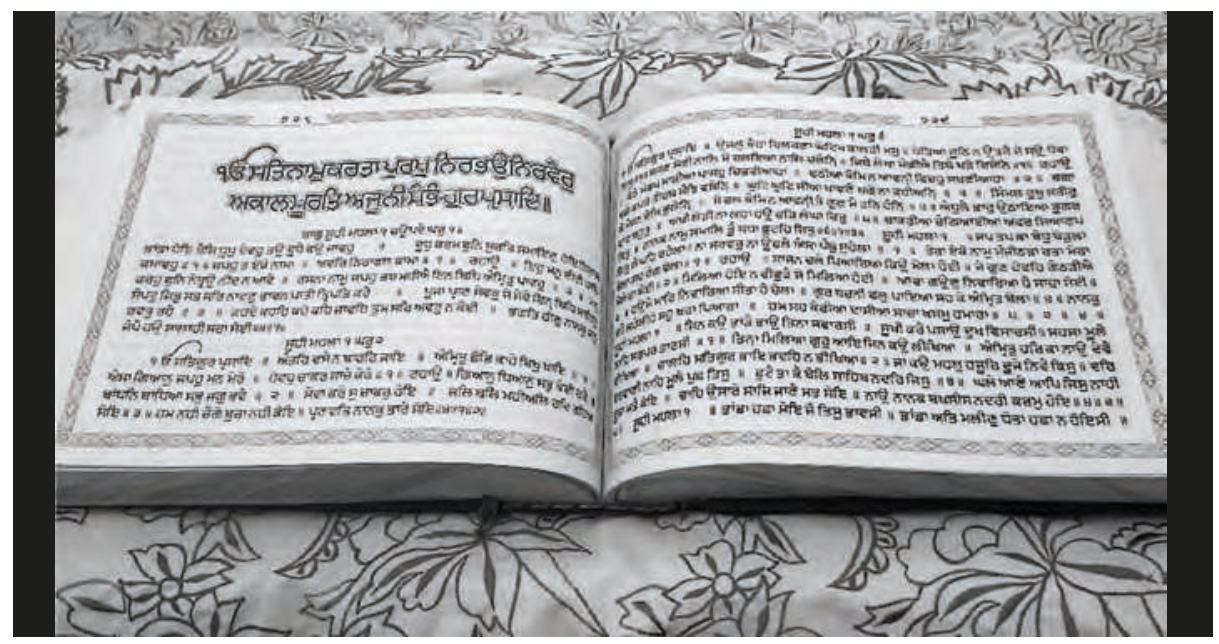

Figure 2. Guru Granth Sahib

(C) Inderjit N. KAUR, 2016

Sabad kirtan continues to be the central mode of worship and devotional expression in Sikhism. The key components of a liturgical service are the ceremonial opening reading of a sabad from the Guru Granth Sahib (hukum vāk, literally spoken command), recitation ( $p \bar{a} t t h$ ) of sabad compositions (bāni), sabad kïrtan, collective prayer (ardās) and the closing reading of a sabad from the Guru Granth Sahib. An additional optional activity is philosophical discourse on the opening sabad of the day, on bāni in general, or on a historical topic. At occasions marking historical events, an important expressive practice is the singing of non-scriptural ballads ( $d h \bar{a} d \bar{l} v \bar{a} r)$. The end of the liturgical session is marked by the distribution of karah parshād (sweet flour pudding) to all the congregants, who then proceed to the dining hall to partake of langar (communal meal) prepared by volunteers in the kitchen on the premises. 
Sikh congregational worship occurs at the gurdwāra (place of worship, lit. doorway to the Guru; see Figure 3). A visit to the gurdwāra is a multi-sensorial and affective experience for Sikhs. Whenever possible, gurdwäras are constructed as grand buildings. The presiding entity in the gurdwāra is the Guru Granth Sahib, which is placed on a raised pedestal covered with ornate scarves under a matching ornate canopy, embroidered with Sikh symbols such as the double-edged sword, khandā, symbolising the significance of both spiritual and temporal engagement in life, mis $\bar{r}-$ pirī. An attendant is always present, fanning an ornate flywhisk, thus, giving Guru Granth Sahib the respect and authority due to a royal leader.

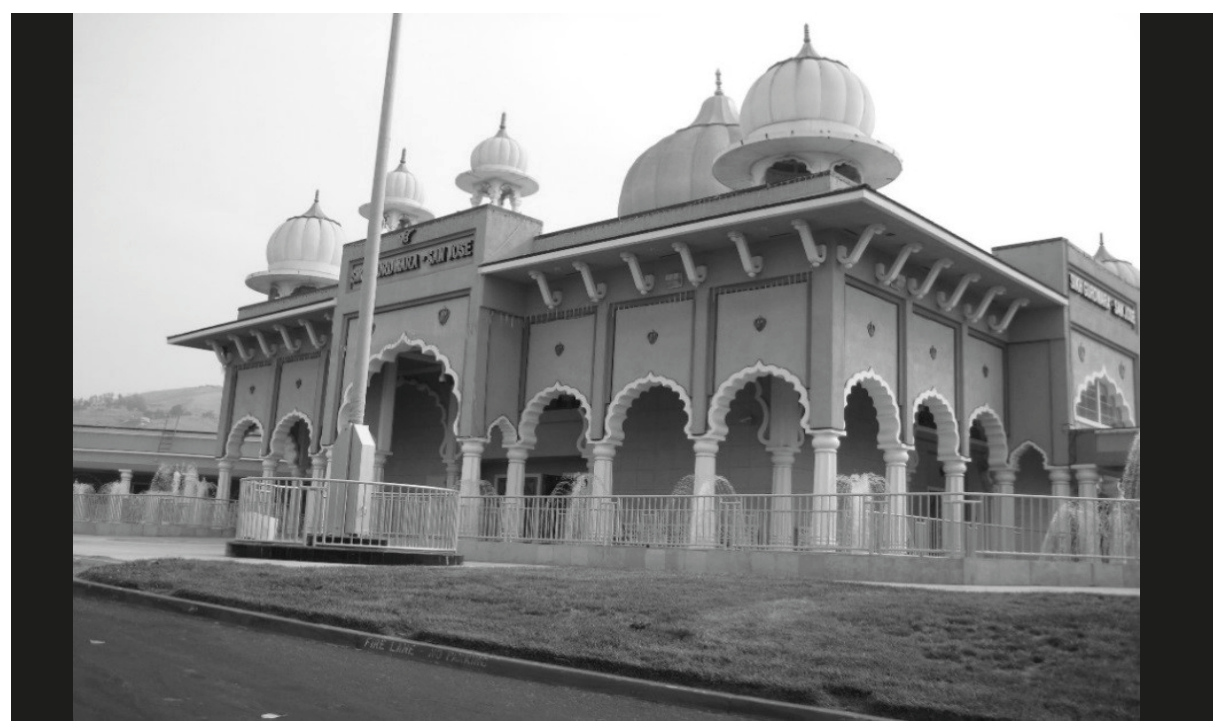

Figure 3. Gurdwāra San Jose, California, USA

(C) Inderjit N. KAUR, 2016

As devotees enter the darbār (sanctuary; lit. royal court), they walk down a central aisle (Figure 4), bow to Guru Granth Sahib (Figure 5), circumambulate around it, receive warm fragrant parshād if they wish (Figure 6), and sit down to enjoy the sweet pudding and the liturgical session in progress (Figure 7). Congregants are encouraged to listen as well as sing in call-and-response format.

The auditory, visual, haptic, olfactory and gustatory, all come together in a gurdwāra experience. The variety of sensorial and embodied kinaesthetic engagements, along with feelings of love and awe for Guru Granth Sahib, as well as the sociality of the congregation, infuse the gurdwāra experience with affective power. The gurdwära is a compelling place, but not without sacred song. The two favourite activities at the gurdwära are listening to sabad kïrtan and eating langar. Sacred song configures not only the congregation but also the subjectivities and identities of its members, as well as their sociality. Affect circulated via sacred songs has been a significant invigorator of the feeling of belonging to a Sikh community. 


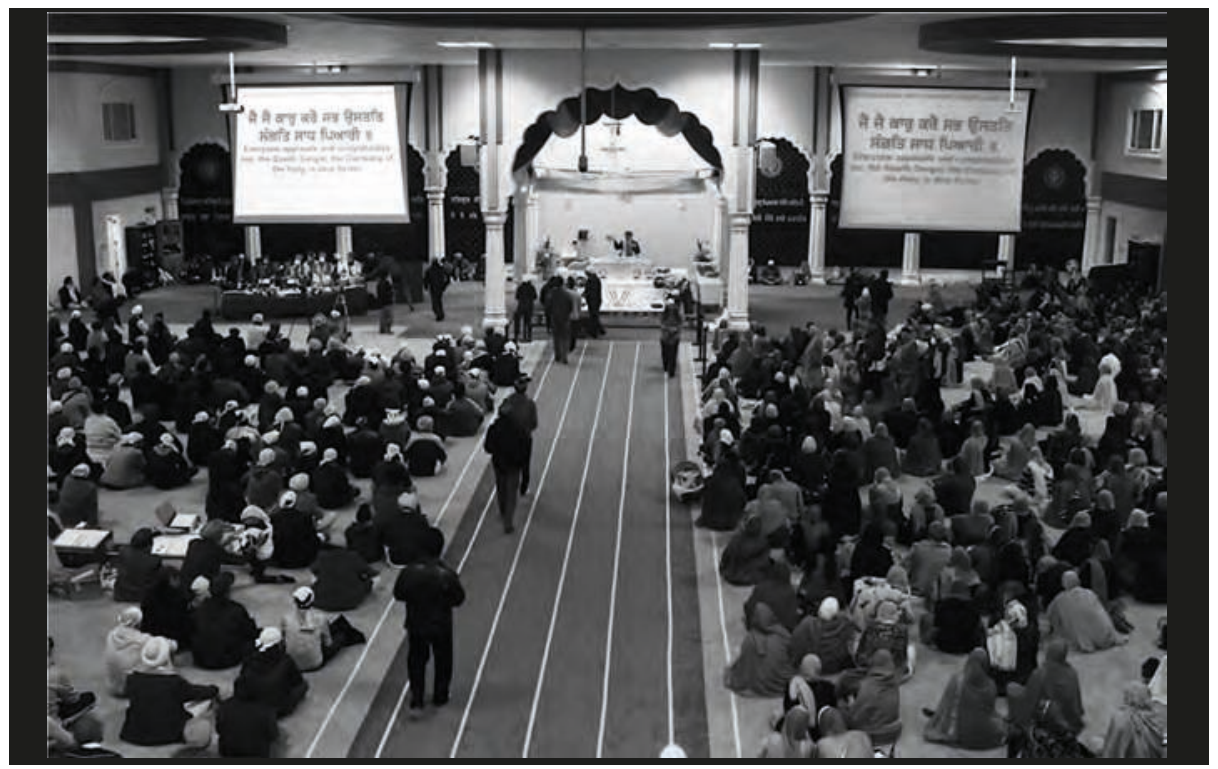

Figure 4. Main sanctuary, Gurdwāra San Jose

(c) Gurdwāra San Jose Facebook page, used with permission

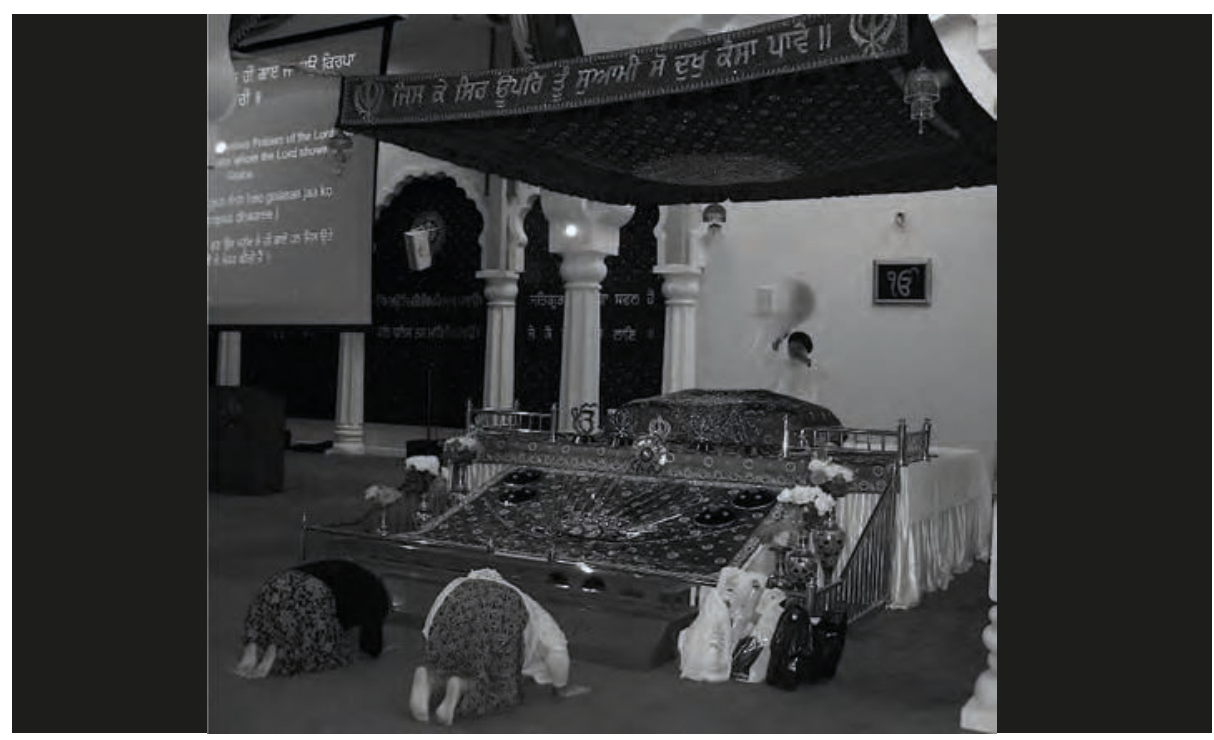

Figure 5. Bowing to Guru Granth Sahib at Gurdwāra San Jose

(C) Inderjit N. KAUR, 2016 
Transnational affects, transnational worldings: Sikhs sounding sacred songs, making multiple worlds

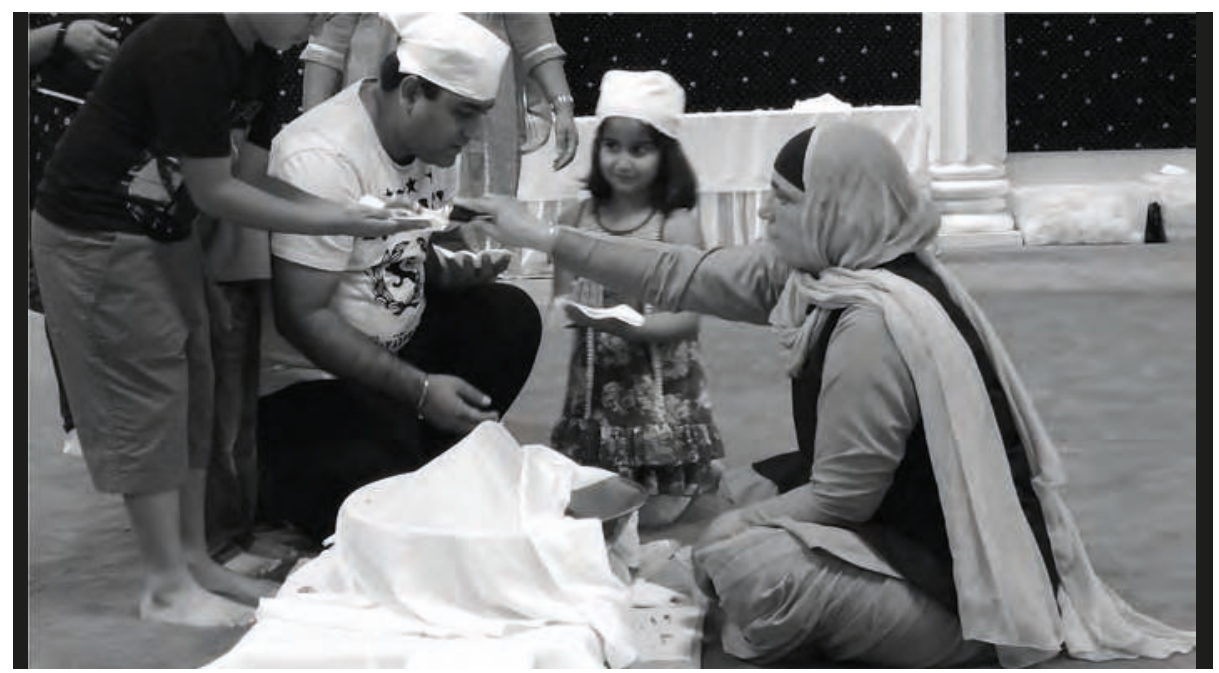

Figure 6. Receiving parshād at Gurdwāra San Jose

(C) Inderjit N. KAUR, 2016

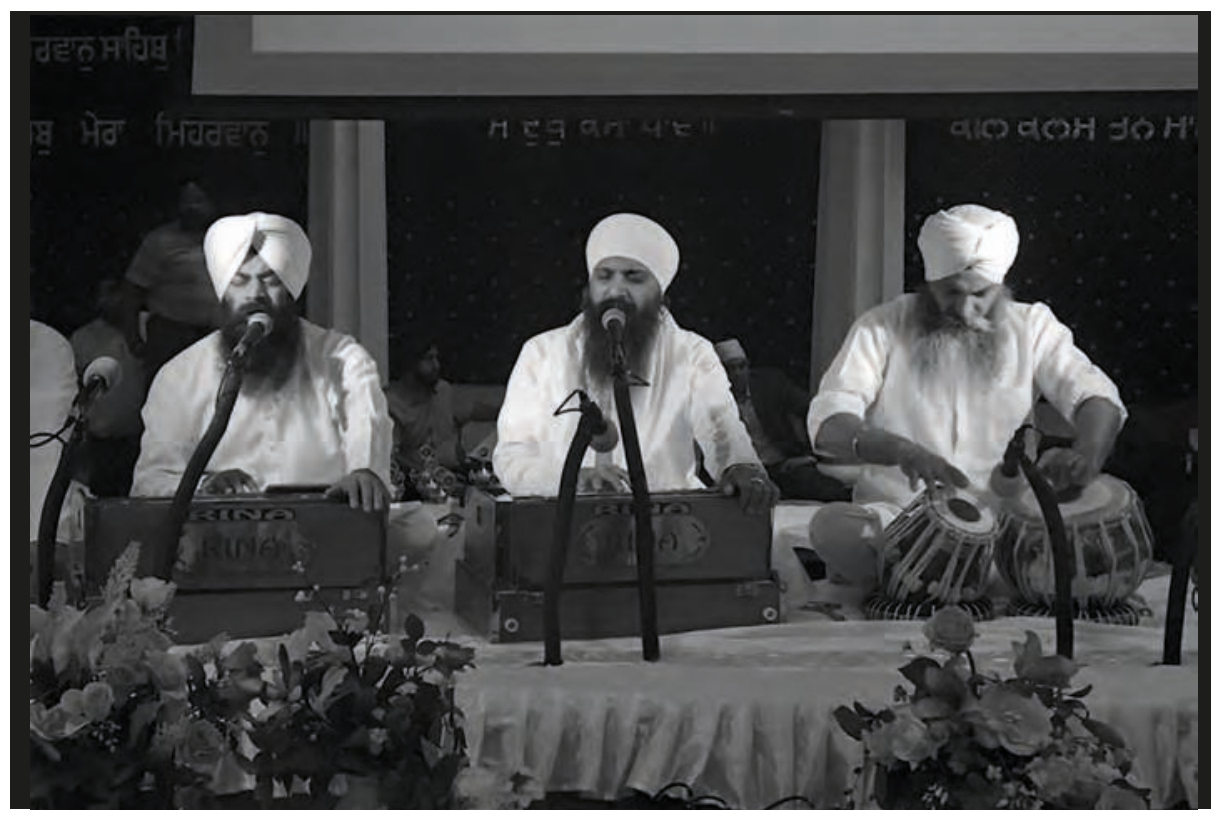

Figure 7. Typical Sikh sabad kīrtan ensemble with harmonium and tabla drums

(c) Gurdwāra San Jose Facebook page, used with permission 
Sabad kirtan is believed to bring a number of benefits such as virtuous living, union with the divine, peace, and healing. Along with divine praise and worship benefits, these song-texts emphasise moral virtues and strongly condemn social difference. Importantly for my purpose here, the songs urge an activist approach to world making. As an example, the text from the popular Asa Ki Vâr (Song of Hope) early-morning liturgical-session states:

\section{भायट गषी भायटा भाये गी राप्तु महातीमै ॥}

Yourself improve your daily affairs.

The sacred songs also break the binary between spiritual advancement and locational mobility with assurances such as:

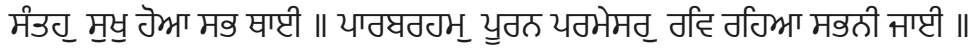

$\mathrm{O}$ virtuous, there is peace everywhere. The perfect transcendent divine dwells everywhere one goes.

As another example of the melding of the transcendent and the immanent, the closing sacred song of the day, when the Guru Granth Sahib is ritually retired to the room of repose, claims:

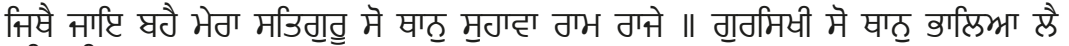 प्रति भुषि फ्याटा ॥ \\ Wherever my True Guru, the divine, resides, that place is pleasing. The Guru's Sikhs seek out that place and embrace it.}

The affective force of such songs combines with that of symbols such as the khanda to unite spiritual and temporal aspirations. The Sikh aesthetic and ethic of chardi kala (optimistic spirit) add further affective power to the pursuit of enterprise. The daily Sikh prayer, ardās, chanted at the end of liturgical sessions, concludes with an assurance that daily remembrance of the divine brings forth chardi kala and sarbat $\bar{a} \bar{a}$ bhalā (welfare for all).

\section{Transnational Sikhs, Sound, Affect}

Sikhs have been on the move across borders for over a century, and along with them, Sikh sabad kìrtan. Technological advances in recent decades, especially in transportation, communication and media, along with certain push factors such as violation of their human rights in India, have increased both the scale and pace of Sikh migration. Jacobsen and Myrvold (2012: 8) note in their edited volume on transnational European Sikhs that "transnationalism is an increasingly important aspect of the Sikh religious and cultural life." The contributing authors of the volume discuss a range of practices that Sikhs actively engage in to participate in transnational social, cultural and religious networks. These include worship practices in gurdwāras, festivals, religious tourism, marriages, and modern media and the internet. 
In this paper, I add three points. First, sacred sound is central to the avenues of Sikh religious transnationalism. Second, the affective dynamics of sound makes it the core strand that pulls together the assemblage of various elements, and invigorates the making of subjectivities and everyday transnational worlds. Third, the transnational affects, subjectivities and worlds show substantial variation at the individual level within transnational communities, and reveal significant nuances that have been collected along different life histories.

The centrality of sabad kirtan stood out clearly in my ethnographic work with transnational Sikhs in the USA, England, and Kenya, and this has also been noted by several authors for different countries and regions, e.g., O'Connell (2000) for Canada, Mann (2000) for the USA, Hirvi (2010) for Finland, Townsend (2011) for Southern California, Jacobsen (2012) for Europe, and Khabra (2012) for United Kingdom and Singapore. Several scholars have noted that transnational Sikhs typically meet to chant and sing initially in private homes, and gradually raise funds to rent a public place, and finally buy or construct a building for a gurdwära. Sacred song is therefore what initiates and sustains the gurdwāra as a place of worship.

What has not been noted by these scholars is the circulation of affect through sabad kirtan. In my earlier work (Kaur 2016), I have discussed that the transmission of affect by means of sabad kirtan and its associated practices is a powerful force bringing the congregants together into "an aggregation of the affected" (Born 2012: 262, selfquoted in 2013: 44).

Here I want to add that the transnational and global circulation of sabad kirtan and accompanying activities has not only enabled Sikhs to engage in worship wherever they have settled, it has affectively linked Sikhs around the world to each other, forming what Grossberg (1984: 227) has termed an ''affective alliance': an organisation of concrete material practices and events, cultural forms and social experience which both opens up and structures the space of our affective investments in the world." Through these transnational practices and affective identifications, Sikhs recognise themselves as a global community.

My ethnographic investigation leads me to propose that this community is a heterogeneous one, with diverse subjectivities as well as multiple forms of belonging. This is especially true of Sikhs who have migrated across nations more than once. Thus, they defy the traditional definition of transnationalism as a link between a home and a host country. Not only do they have multiple "host" countries, the "home" country shifts as well, particularly for successive generations, as I will show in a following story.

Related to such diverse histories, transnational affects take varied and complex shapes and hues. It is not merely a translocal transposition of affects from Punjab to other locations. Wise and Velayuthum (2008: 113) have used the term "transnational affect" "to describe the function of bodily emotions such as shame and pride that compel participation in and conformity to the transnational social field." Their interest has 
been to show how such sentiments are replayed in translocal contexts to reproduce locality. My purpose here is to explore how affects accrue and take possibly varied forms; how they make for new subjectivities and worldviews, and pour into diverse and changing everyday world-makings.

\section{Transnational Worldings}

Stewart has drawn on Heidegger's notion of "worlding" which emphasises being in the world as emergent and generative, always in process, always bringing forth meaning. For Stewart a worlding is a coming together of affective elements of life. She writes, "The intensities of living through things accumulate and pool up in worldings and forms of attending to what's happening." (2011: 452). Worldings have sensory and aesthetic qualities; they are dynamic. A worlding comes forth when "[s] omething reaches a point of expressivity" (2014: 119). Stewart urges attention to the "atmospheric attunements" (2011: 445) that generate worldings and "to write theory through stories, or try, through descriptive detours, to pull academic attunements into tricky alignment with the amazing, sometimes eventful, sometimes buoyant, sometimes endured, sometimes so sad, always commonplace labor of becoming sentient to a world's work, bodies, rhythms, and ways of being in noise and light and space (Nancy 1997)" (ibid: 446).

Here I explore this approach by investigating similar processes of worlds taking shape, but those that are animated by transnational affects as I have conceptualised it above. These transnational worldings are made of things local and global at the same time; the attunements that make up these worldings across-nations.

\section{Rupinder (from Kenya) in Texas: "Where the heck am I sitting?"}

Were it not for her husband's choice, Rupinder would move back to Kenya in a heartbeat. She was born in Kisumu, East Africa (now Kenya) in the 1950s. Her grandfather had migrated from his village in Punjab, India, in search for better job prospects, and a life unhampered by caste.

\footnotetext{
My grandpa was well educated, but was not getting a job in his village because of his caste; he was downgraded. I'm not going to take it, he said. He was adventurous. When he went back to visit, they said, Oh, you live in Africa? Do you live in trees? $\mathrm{He}$ was not happy to go back there; koi lor nai utthe jān di, koi respect nahi karda (There is no need to go there, no one respects).
}

Sikh migration to East Africa dates to the end of the $19^{\text {th }}$ century, when they were brought along with other Punjabis and Indians, as indentured labour to work on the British Kenya-Uganda rail line from the Indian Ocean port of Mombasa to Kampala. These Sikhs were largely from the artisan class in Punjab whom the land-owning class considered inferior. But in East Africa their status was elevated, though for unfortunate reasons. The British established a strictly segregated three-tier class system along racial lines with Africans placed at the bottom. Sikhs, as skilled labour, were able to make rapid economic gains, and their relative social uniformity was an important factor that helped forge a strong community. 
I miss both time and place. Scruples and morals have been compromised, dīn imān nahi rahyā (faith doesn't exist anymore). When I was growing up in East Africa, we did things properly.

She is referring to the etiquette of attending to the Guru Granth Sahib, and the programs of sacred sound. She particularly remembers the occasions of akhand pātth (continuous complete reading of Guru Granth Sahib) which typically culminates in sabad kirtan.

Akhand pātth kinne pyār nāl rakhde si (We did akhand pātth with so much love). We were hardly ten [years old], and we were taken [to the gurdwāra]; we did sevā (service). Getting there the night before, washing the gurdwāra floor, drying it. Women would get there ahead of time, make the menu ... freshly made food ... serve the langar. Also, akhand pātth at home. My duty was to make badāmāin da dudh (milk with almonds) at 10, to serve the pätthi (chanter) at night ... When you have grown up with so many principles ... now everything is money minded. Everyone kept to their Sikhi (Sikh teachings). We had a strict gyäni (religious scholar). We went [to the gurdwāra] in the evening, on Saturdays; you have to listen to kìrtan, then sevā, langar, bhānde mānjney hai (have to wash dishes) - first remove the food, scrub them in the sawdust mound, then use soap and water. Women also formed active women's associations. We went regularly to St. Bernardo's [orphanage] to donate clothes and other items. We would mix with the matrons, play with the kids. I'm so nostalgic for getting any form of sevā. Women that I grew up with, my mom, were very strong, dedicated, and extremely professional in their attitude toward Sikhi.

Rupinder is passionate about sabad kīrtan.

Kìrtan is $j \bar{a} n$ (life, in the sense of vital force). We were blessed we always had awesome kìrtan; never remember kìrtan as not good. When I was little, we used to go to the gurdwāra Landia Sahib - old gurdwāra, during railways being constructed; all working lived there and went there. It became a blessed place, because of Baba Isher Singh ji Rahrhe Wale (spiritual guide from village Rahrha, Punjab). You can 'google' him. He did siddhi dhārna kīrtan (simple kìrtan in dhärna style). ${ }^{3}$ It is authentic kìrtan, without $r \bar{a} g$; it was there along with $r \bar{a} g$ (melodic modes of Indian classical music). He first did shān (instrumental prelude), two to five minutes; it can get you to a meditative state, lot of spiritual bliss; on $v \overline{a j} a$ (harmonium), he took high sur (notes) and bass sur; deep high bass tune, plain tune, with obviously something linking him to kirtan. He had some way of hypnotising the sangat (congregation); there was always pin drop silence when he sang. I've been listening to siddha (simple) kirtan in childhood, and up to now. I also love classical [style] kīrtan; jad rāg vich karde hun (when they play in $r \overline{a g}$ ), you are in cloud nine man! Some modern tunes are also good.

3 Dhārna style is a simple, light style kïrtan popular in villages. Dhärna means concept. The singer takes a devotional phrase and builds on it adding thematically related sacred songs to it. It is sung in call and response format accompanied with a harmonium, drums (typically dholki) and handheld idiophones such as chhainé (cymbals) and kartāl (shakers). 
The sacred songs, singers, and instruments Rupinder loves are from India, but it is in Kenya that their potentialities fully bloom for her.

Yes, I'm an American citizen, but in my heart I will always be Kenyan. I tell my dad, as soon as the plane lands, my soul says I am home ... I have amazing memories of that soil. Food is amazing there. Now American and British are getting there; they will spoil it. Food tastes like food, not GMO. I am so blessed with the food I ate there. And sports with local kids.

But Rupinder also refers to herself as Indian, though in uncomplimentary terms.

We as Indian are by nature very racist. We say, gori kuri hai bahut soni hai (the girl is fair, is very beautiful). I've heard it from educated couples.

Rupinder's sensibilities have developed from her years in East Africa, along with Sikh teachings she has imbibed through the sacred songs. She regrets the racist attitude of early Indian immigrants to East Africa.

Initially, grandparent's generation were racist toward kale (blacks); I did not like it, questioned it. On the flip side, the servants were part of the family. My generation was different, we had a different attitude to the locals. I had local friends, went to their home ... ate their food. This generation, when I go back now, people in their 30s now, are even more progressive. They have an amazing sense of being Kenyan. I was there last year, they talk and act British. Everyone is very tolerant. Especially after the Westgate Mall terrorist attack. I never knew about the caste system till I came to the USA. My parents were never into $j \bar{a} t-p \bar{a} t$ (caste). I grew up so cosmopolitan, my friends were Ismaili, Gujrati, local girls. All came home, ate. When we got to America, and England, Sikhs are so caste conscious, it blew my mind; that is when I went back to my parents and questioned, and they were disheartened that they had tried to go past it.

Rupinder's worlding is an accumulation of intensities, from the embodied experiences of worship activities in Kenya, and their felt lack in the USA; from the freedom to practice religion, and freedom from caste in Kenya, and the felt restrictions in the USA - the bias against turbans and beards by the majority of Americans, ${ }^{4}$ and the caste consciousness among Sikhs in the USA. Her ideal Sikh world resides not in Punjab, India, the homeland of Sikhs, but in Kenya. It is Kenya that afforded her best Sikh practices as she sees them (and hears in sacred songs) - of equality and embodied community service.

Memories of Kenyan worldings infuse the present for Rupinder. Her worlding is an attunement to the loss of embodiment, of what she calls "the proper way of doing things," of living a "true" Sikh life, "simple," with "principles." While the sacred songs and sounds link her to Sikhs globally, her micro Sikh world is particular; her subjectivity, her identity and sense of belonging unique. And despite the strong identification with Kenya, the feeling of unsettlement comes through in a little sentence. "We are basically gypsies everywhere," she says. Perhaps, she is referring to the worldwide dispersal of Sikhs in response to recurrent religious and ethnic violence against them in India, such as the 1947 partition of Punjab, allotting the western part to the newly formed Islamic state, Pakistan, and the eastern part to an ostensibly secular Hindustan (India); and the 
1984 Indian state sponsored anti-Sikh pogroms. ${ }^{5}$ Or perhaps Rupinder is referring to dwelling itself as travelling as Jim Clifford (1997) has expounded. But about certain things Rupinder is clear:

I am blessed to be born Sikh; I am a sucker for kïrtan, and for Kenya.

Kuljit (from India) in California: “I lived 21 years in India, but I learned Sikhi here”

Unlike Rupinder, issues of caste do not ring strong in Kuljit's intensities. She is from an upper caste family, and uses a last name that indicates this. While Sikhi condemns belief in caste and class differences, in practice many Sikhs have retained caste associations inherited from their family's past. The last human Sikh Guru mandated that Sikhs not use last names that indicate caste, but instead use generic last names - Kaur for women and Singh for men (Sikh first names are ungendered). But many Sikhs, especially upper caste ones, continue to use their caste names, though many cite the reason as the problem of identity with a common last name instead of a family name. Caste differences, like economic class, play out in social life, particularly matrimony. Exclusionary practices at $g u r d w \bar{a} r \bar{a} s$ are not typical however, though there are gurdwārās with sectarian names and congregations.

Like Rupinder, Kuljit loves sabad kirtan and pātth, and listens to these not only at the gurdwāra, but throughout the day at home, on her iPhone and television. Apps such as Live Kirtan and SikhNet Radio relay live broadcasts from many gurdwārās in India and around the world.

There is so much choice whenever I need it. Many times, I cannot get to sleep quickly. I just listen to the live relay from Harmandir Sahib.

Harmandir Sahib, known popularly as the Golden Temple, is the holiest Sikh place of worship, located in Amritsar, Punjab. It is the most popular site of pilgrimage for Sikhs. Live sabad kirtan is performed and broadcast continuously from about 2.00 am to $10.00 \mathrm{pm}$. Sikhs around the world tune in (Figure 8). For many, the hukamnāmā (day's opening chant from the Guru Granth Sahib; lit. command) from the Harmandir Sahib is especially meaningful. The purpose of listening is to infuse the day's dealings with the Guru's guidance in that song.

Like Rupinder's love for sabad kirtan, Kuljit's also started in childhood, in the company of her mother. She remembers fondly her mother taking her along to sabad kìrtan programs in their neighborhood gurdwāra in Delhi. Her favourite memories are of the Wednesday afternoon istri satsang (women's congregation led by women without professional priests). ${ }^{6}$

5 For scholarship on Hindu nationalism and violation of minority rights in India, see e.g. Narula 2003.

6 In Sikh practice, all rituals can be conducted by a lay person; a professional priest is not required. Worship and ritual practice without professionals is recommended and encouraged, even though professionalisation and institutionalisation were instated right from the beginning by the founder of Sikhi, Guru Nanak. 
I remember all the women singing; one would play the $v \bar{a} j \bar{a}$ (harmonium), another dholkī, also chhainé. It was so soothing ... many times I would put my head on my mummy's knees and fall asleep. I didn't understand the words, but I loved the music. I also loved the raein sabāi (all night kìrtan sessions) at the gurpurab (celebrations; lit. Guru's days) when they would set up huge tambu (pavilions) next to the gurdwāra. Now I am blessed that the gurdwāra here [San Jose] has all the programs and celebrations.

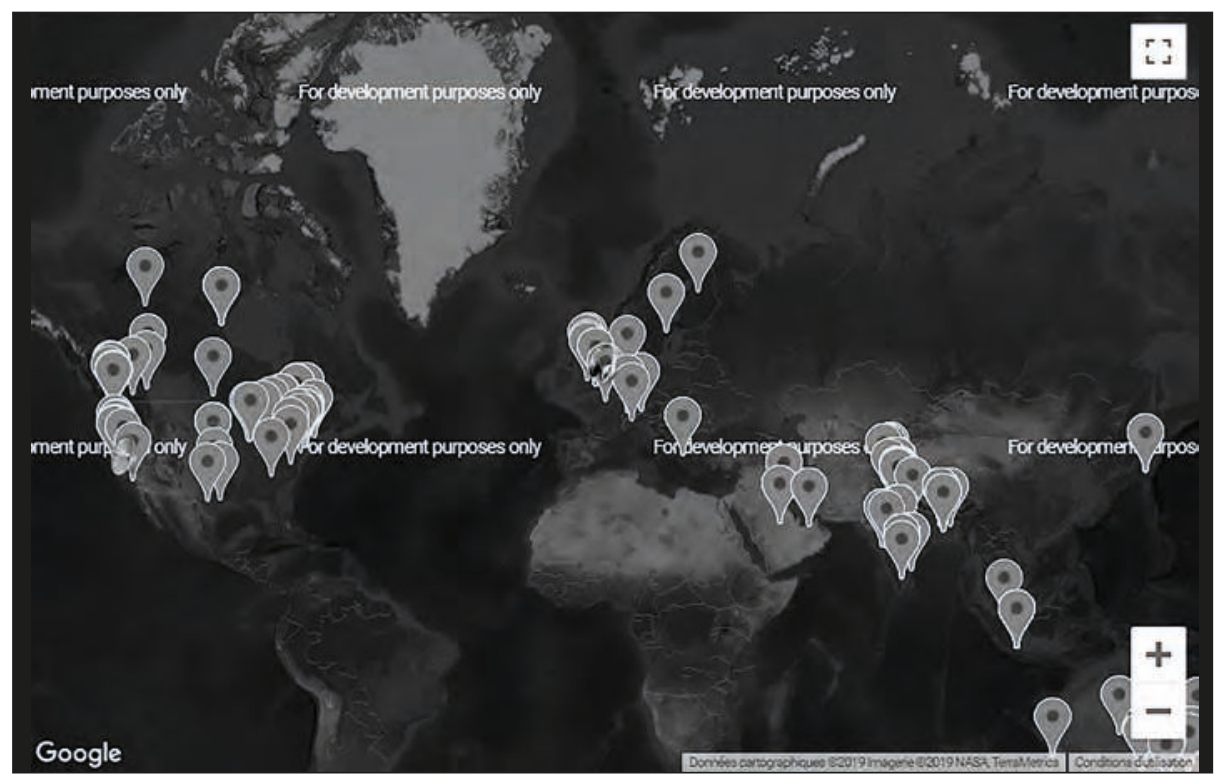

Figure 8. Listener Map, sikhnet.com Live radio from Harmandir Sahib

(C) www.sikhnet.com/radio/channel50

Kuljit's childhood worship attunements are to being soothed, to sliding in and out of states of consciousness. These infuse her present attunements. Her kids are grown and out of the house. Elders who she looked after at her home have passed on. She is alone at home all day.

I start the day, with listening to the hukam vāk from Darbar (Harmandir) Sahib. Kìrtan, $k a t h \bar{a}$ (exegesis), it's on all day at my home; sometimes I'm not paying attention, par gurbāni kannā vich té pae rahi hai (but the Guru's word is at least pouring into my ears). Sometimes I feel I am at the Darbar Sahib. I love to sing along when I know the words. If it is an unfamiliar sabad it catches my attention. Yesterday the kirtan from Darbar Sahib had many Farsi (Persian) words. I looked up the meanings on my iPhone. ${ }^{7}$ I like to contemplate on the meaning of the words; what is being taught to us. When I am at the gurdwāra, I listen with full concentration.

7 Several smartphone apps, as well as internet sites, have the digital version of Guru Granth Sahib, along with English and/or Punjabi translations. 
Like Rupinder, sevā has been very important for Kuljit. But for Kuljit it has meant serving her aging father and mother-in-law in her own home.

I grew up with that. My dādi (paternal grandmother) lived with us, also my dad's täi ji (paternal aunt), because her children did not want to look after her. My mother died early, when I was only twenty, but I saw my father look after his ill mother with utmost devotion.

But what Kuljit is referring to has been a (Punjabi, and more generally Indian) patriarchal tradition of elder care in a son's home. In this tradition, not only is it customary for elders to be housed by their sons, it is a matter of shame to live in a daughter's home, especially when one has sons. Kuljit was able to break from the traditional homecountry mold in her transnational setting to have her father at her home when the arrangement fell apart at her brother's home who lives nearby in the same town.

I could not bear it that my father would rent a room in someone's home. He agreed to stay in my house, but only on the condition that he would give me monthly rent. I said, fine, you are my father, you can give me money.

Perhaps for Kuljit being an exemplar to her three daughters played a part; perhaps also her attunement to the song-texts that valorise equality and courage. Unlike Rupinder, Kuljit has no nostalgia for her place of birth and growing-up. She was born and raised in Delhi, India. Interestingly then, the two share a common lack of wistfulness for India, and have no desire to live there.

Life is more peaceful here. I have more time to pay attention to my religion. I lived 21 years in India, but I learned Sikhi here.

She does not think living in the USA is a handicap.

Only for those who are not educated. They are pressured to remove their turbans and shave their beards; otherwise they don't get jobs.

Unlike Rupinder, Kuljit thinks of herself fundamentally as Indian, and loves to travel to India. She loves travelling in general, but travelling in India affords her the opportunity to also visit historic Sikh sites along with notable tourist attractions.

Two years ago we went to Hyderabad. We could visit the gurdwāra at Nanded, and also Aurangabad to see the marvelous Ellora caves. This year we are going to Hemkunt Sahib, but we will also see the Valley of Flowers. And on the way we will stop in Japan and tour the country for ten days.

Thus, for Kuljit, rather than travel as only pilgrimage, pilgrimage and general travel combine easily; she can move between sacred and secular effortlessly.

Kuljit's subjectivities, like Rupinder's are not mere replications from a home to a host country. Travelling and dwelling combine in different ways for them in the making of their transnational lifeworlds. Spiritual and transnational ambitions and mobilities come together in diverse ways. Thomas Csordas (2017: 1) has discussed such convergences as "transnational transcendence." Underscoring the under-theorisation of religious transnationalism, he uses this phrase "to point to the existence of modalities of religious 
intersubjectivity that are both experientially compelling and transcend cultural borders and boundaries;" to indicate that both senses of transcendence, of consciousness and borders, are aspirations to the universal. The sabad-texts quoted above, along with the Sikh ethic of $m \bar{i} r \bar{r}-p \bar{r} r \bar{l}$, are interpreted as such by Sikhs.

\section{Concluding comments}

In this paper, I have investigated the role of sacred song in religious transnationalism through the lenses of affect and worlding. This new approach, combined with the storytelling methodology, has enabled me to provide insights on the complex, multilayered and diverse processes of subjectivity and identity formation of transnationals at the individual level. I have thereby complemented the focus thus far of scholarship largely on group-level analysis of the role of affect on transnational social formations.

Additionally, I have offered a more dynamic conceptualisation of transnationalism as a continually moving mix of mobility and locality.

My ethnographic investigation shows that it is important to recognise transnational religious linkages as flows of affect, and transnational subjectivities and identities as dynamic affective becomings. Rather than a transnational transposition of fixed affects and locality, it is their transformation, however small and gradual, that is voiced by my interlocutors. I have therefore proposed an expanded conceptualisation of "transnational affects" to draw attention to the accrual of affects across borders not simply as a transference of affects, but as dynamic intensities that acquire different textures as people and generations cross borders.

My interlocutors' stories are of transnational embodied flows and accruals of affects that actualise in formations of subjectivities and identities with respect to social difference such as caste, race, and gender. Their worldings are outcomes of new affect attunements, with new hues and flavors. Rupinder and Kuljit recall and gather together elements and intensities not just from India; for Rupinder these are from India, Kenya, and the USA; for Kuljit, India, the USA, and all the countries she visits to combine her wanderlust with pilgrimage. Their worldings bloom forth from various cross-border zones of sensory and affective interactions and connections, each with many commonalities but also differences. I have conceptualised this in terms of "transnational worldings," to foreground how elements from across borders enter into everyday process of world making. Sacred song is still central, still matters, but it matters in ways that have been changed, and are in continuous flux.

I have made my arguments through two stories of transnational worldings, one of satisfaction, the other not; with sacred sound central to both, and seva central to both, but in different ways; one sensitised to race and caste, the other to gender. The scope remains to tell many such stories that space constraints do not allow here, stories of simultaneous commonness and uniqueness, of simultaneous localness and globalness. For example Harinder, who grew up in a small village in Punjab in the 1950s in the care of a strong and social-activist grandmother while her parents made a livelihood 
in East Africa. She now lives in California, and loves to listen to the sabad kirtan and experience the sangat (congregation) at the local gurdwära, but hates being preached to by old-fashioned male priests, and she wishes for greater social action by Sikhs. Or Baljeet, who grew up in Delhi with a progressive father, moved to California to join her husband, and finding him patriarchal and controlling, took solace from the daily chanting of sacred songs; then found wisdom and strength from these to eventually stand up against him when he disowned their daughter for marrying outside the faith. These stories point to the capacious potentials in sacred song, affect, and transnational worldings.

My study of the transnational circulation of Sikh sacred song and of commonplace Sikh lives tells us how sacred sound is a critical connective tissue between Sikhs across nations; how it both enables and is enabled by affective embodied experiences, which mutually form what I have elsewhere described as a "Sikh affective ecology" (Kaur 2016a, 2019); and how while being part of this transnational ecology, transnational affects and worldings are individual, unique, and fluid.

\section{References}

Ahmed, Sara, 2004. The cultural politics of emotions. Edinburgh: Edinburgh University Press.

Brennan, Teresa, 2004. The Transmission of Affect. Ithaca, NY: Cornell University Press.

Born, Georgina, 2013. Music, sound and space: Transformations of public and private experience. Cambridge: Cambridge University Press.

Csordas, Thomas J. (ed.), 2017. Transnational transcendence: Essays on religion and globalization. Berkeley, CA, \& London, UK: University of California Press.

Clifford, James, 1997. Routes: Travel and translation in the late twentieth century. Cambridge: Harvard University Press.

Ferran, Hugo, 2015. "The Ethiopian and Eritrean evangelical diaspora of Montreal music, identity and ambivalence," African Diaspora 8 (1), pp. 76-97.

Gilroy, Paul, 1993. The Black Atlantic: Modernity and double consciousness. London: Verso.

Gregg, Melissa \& Gregory J. Seigworth, eds, 2010. The affect theory reader. Durham, NC \& London: Duke University Press.

Grossberg, Lawrence, 1984. "Another boring day in paradise: Rock and Roll and the empowerment of everyday life," Popular Music 4 (Performers and Audiences), pp. 225-258.

Hall, Stuart, 1990. "Cultural identity and diaspora," in Jonathan Rutherford (ed.), Identity: Community, culture, difference, pp. 222-237. London: Lawrence \& Wishart.

Heidegger, Martin, 1962. Being and time. New York: Harper \& Row.

Hirvi, Laura, 2010. "The Sikh Gurdwara in Finland: Negotiating, maintaining and transmitting immigrants' identities," South Asian Diaspora 2 (2), pp. 219-232.

Jacobsen, Knut A., 2012. "Tuning identity in European 'Houses of the Guru': The importance of gurdwaras and Kirtan among Sikhs in Europe," in Knut A. Jacobsen \& Kristina Myrvold (eds), Sikhs across borders: Transnational practices of European Sikhs, pp. 105-118. New York: Bloomsbury.

Jacobsen, Knut A. \& Kristina Myrvold (eds), 2012. Sikhs across borders: Transnational practices of European Sikhs. New York: Bloomsbury.

Kaur, Inderjit N., 2011. "Sikh Shabad Kīrtan and Gurmat Sangīt: What's in the Name?" Journal of Punjab Studies, 18 (1-2), pp. 251-278. 
Kaur, Inderjit N., 2016a. When 'Unheard sound' (re)sounds: Affective listening, ethical affects, and embodied experience in Sikh Sabad Kïrtan. PhD dissertation, University of California, Berkeley.

Kaur, Inderjit N., 2016b. "Multiple authenticities in motion: Styles and stances in Sikh Sabad Kīrtan," Yearbook of Traditional Music 48, pp. 71-93.

Kaur, Inderjit N., 2019. "A multisensorial affective ecology of sonic worship: The Sikh sacred song tradition," MUSICultures 45 (2).

Khabra, Gurdeep J. S., 2012. "Music of the Sikh diaspora: Devotional sounds, musical memory and cultural identity," Sikh Formations 8 (2), pp. 147-170.

Massumi, Brian, 2002. Parables for the virtual: Movement, affect, sensation. Durham, NC: Duke University Press.

Narula, Smita, 2003. "Overlooked danger: The security and rights implications of Hindu nationalism in India," Harvard Human Rights Journal 16, pp. 41-68.

O'Connell, Joseph T., 2000. "Sikh religio-ethnic experience in Canada," in Harold G. Coward, John R. Hinnells \& Raymond B. Williams (eds), The South Asian religious diaspora in Britain, Canada, and the United States, pp. 91-209. Albany, NY: State University of New York Press.

Purewal, Navtej Kaur \& Hardinder Singh Lallie, 2013. "Sikh Kirtan in the diaspora: Identity, innovation and revivalism," in Michael Hawley (ed.), Sikh diaspora: Theory, agency, and experience, pp. 381-404. Leiden \& Boston: Brill.

SALDEF and Stanford University Peace and Innovation Lab, 2013. Turban myths: The opportunities and challenges for reframing Sikh American identity in Post-9/11 America. A report by SALDEF (Sikh American Legal Defense and Education Fund) and Stanford University.

Salzbrunn, Monika, 2016. "When the mosque goes Beethoven: Expressing religious belongings through music," Journal of Comparative Research in Anthropology and Sociology 7 (1), pp. 59-74.

Singh Mann, Gurinder, 2000. "Sikhism in the United States of America," in Harold Coward, John R. Hinnells \& Raymond B. Williams (eds), The South Asian religious diaspora in Britain, Canada, and the United States, pp. 259-276. Albany, NY: State University of New York Press.

Stewart, Kathleen, 2011. “Atmospheric attunements," Environment and Planning D: Society and space 29, pp. 445-453.

Stewart, Kathleen, 2014. "Tactile compositions," in Penny Harvey, Eleanor Conlin Casella, Gillian Evans, Hannah Knox, Christine McLean, Elizabeth B. Silva, Nicholas Thoburn \& Kath Woodward (eds), Objects and materials: A Routledge companion, pp. 119-127. London \& New York: Routledge.

Slobin, Mark, 2011. "The destiny of 'diaspora' in ethnomusicology," in Martin Clayton, Trevor Herbert \& Richard Middleton (eds), The cultural study of music: A critical introduction $\left(2^{\text {nd }}\right.$ Edition), pp. 284-296. New York: Routledge.

Townsend, Charles, 2011. "Gurbani Kirtan and the performance of Sikh identity in California," in Pashaura Singh (ed.), Sikhism in global context, pp. 208-209. New Delhi: Oxford University Press.

Vannini, Phillip (ed.), 2015. Non-representational methodologies: Re-envisioning research. New York \& London: Routledge.

Velayutham, Selvaraj \& Amanda Wise, 2005. "Moral economies of a translocal village: Obligations and shame among South Indian transnational migrants," Global Networks 5 (1), pp. 27-47.

Wise, Amanda \& Selvaraj Velayutham, 2008. "Second-generation Tamils and cross-cultural marriage: Managing the translocal village in a moment of cultural rupture," Journal of Ethnic and Migration Studies 34 (1), pp. 113-131. 